\title{
Removal of High C and N Contents in Synthetic Wastewater Using Internal Circulation of Anaerobic and Anoxic/Oxic Activated Sludge Processes
}

\author{
Nittaya Boontian \\ School of Environmental Engineering, Institute of Engineering, Suranaree University of Technology
}

\begin{abstract}
Internal circulation (IC) of activated sludge anaerobic and anoxic/oxic processes was used to treat high carbon $(\mathrm{C})$ and nitrogen $(\mathrm{N})$ synthetic wastewater in order to achieve an effluent standard. The $1^{\text {st }} \& 2^{\text {nd }}$ internal circulation anoxic (ICA) has shown a great advantage. Because under anoxic conditions heterotrophs utilize organic matter (OM). OM and $\mathrm{NO}_{3}{ }^{-}-\mathrm{N}$ are an electron donor and an electron donor, respectively. As a result, under conditions high carbon and $\mathrm{NO}_{3}^{-} \mathrm{-}, \mathrm{N}_{2}$ production can generate higher than with $1^{\text {st }}$ ICA BNR system only. Aerobic IC to anoxic, $1^{\text {st }}$ ICA, and effluent IC to anoxic, $2^{\text {nd }}$ ICA, could remove $100 \%$ of COD, $99.60 \%$ of TKN, and $99.90 \%$ of $\mathrm{NH}_{4}{ }^{+}-\mathrm{N}$. The organic loading rate and $\mathrm{NH}_{4}{ }^{+}-\mathrm{N}$ loading rate are $68.38 \mathrm{~kg}-\mathrm{COD} \mathrm{m}{ }^{-3} \mathrm{~d}^{-1}$ and $9.86 \mathrm{~kg} \mathrm{NH}_{4}{ }^{+}-\mathrm{N} \mathrm{m}^{-3} \mathrm{~d}^{-1}$, respectively in synthetic wastewater. Performance of these ICA activated sludge treatment was achieved the discharge standard with effluent $\mathrm{COD}$ less than $0 \mathrm{mg} \mathrm{L}^{-1}$,effluent $\mathrm{NH}_{4}{ }^{+}-\mathrm{N}$ less than $4 \mathrm{mg} \mathrm{NH}_{4}{ }^{+}-\mathrm{N} \mathrm{L}^{-1}$, effluent $\mathrm{NO}_{2}{ }^{-}-\mathrm{N}$ less than $0.1 \mathrm{mg} \mathrm{NO}_{2}^{-}-\mathrm{N} \mathrm{L}^{-1}$, and $\mathrm{NO}_{3}{ }^{-}-\mathrm{N}$ less than $0.02 \mathrm{mg} \mathrm{NO}_{3}{ }^{-}-\mathrm{N} \mathrm{L}^{-1}$.
\end{abstract}

\section{Introduction}

Biological nitrification-denitrification is the most commonly used process for nitrogen removal from industries handling protein-rich materials or other nitrogen compounds generate, effluents with very high loads of ammonia. The degree of treatment required and the selection of suitable treatment technique are usually dependent upon the wastewater composition. A post treatment may be required mainly to remove ammonia before discharge and biological nitrificationdenitrification being the most extensively used process. As the $\mathrm{C} / \mathrm{N}$ ratio after anaerobic digestion is generally insufficient for denitrification, the main challenge in combining the anaerobic digestion process with an activated sludge nitrification/denitrification process lies in the management of organic matter (OM). Optimize the management of $\mathrm{OM}$ between the anaerobic and anoxic/oxic reactors. For that, proposed a combined process based on an anaerobic phase followed by an anoxic/oxic reactor in order to removal nitrogen by nitrification/denitrification. To provide enough effluent denitrification in the anoxic/aerobic reactor, a fraction of the effluent was fed directly to the anoxic/oxic reactor. This study focused on the use of recycled effluent. Operating reactor with pumping the water from effluent to anoxic zone could significantly increase the effluent quality. The purpose of this work was to present the design and functionality of a lab-scale dynamic effluent activated processes for biological removal of organic substrate and nitrogen applying anoxic-oxic process.

\section{Material and methods}

\subsection{Process configuration}

The system (Fig. 1) and the operating design for each instance of influent flow rate, reactor volumes, return sludge ratio, internal recirculation flow rate ratios, hydraulic retention time (HRT), solid retention time (SRT) and $\mathrm{O}_{2}$ concentration were obtained from lab scale results. These are given in Table 1. This lab scale processes consisted of four reactors in series. They included anaerobic, anoxic, aerobic phase and clarifier stages with effective volumes $5,5,20$ and $30 \mathrm{~L}$, respectively. In addition, the total HRT of anaerobic, anoxic and aerobic conditions, and SRT were $12 \mathrm{~h}$ and 20 days, respectively. The operating conditions of this system were: influent wastewater flow rate, return activated sludge (RAS) flow rate, $1^{\text {st }}$ and $2^{\text {nd }}$ internal circulation anoxic (ICA) flowrate. $\mathrm{O}_{2}$ concentration was maintained between $2-4 \mathrm{mg} \mathrm{L}^{-1}$ in the aerobic zone. Average process temperature was maintained at $37^{\circ} \mathrm{C}$.

Table 1. The operation condition for lab-scale biological nutrient removal (BNR) treatment plant.

\begin{tabular}{|c|c|c|c|}
\hline Flow rate & Unit $\left(\mathbf{L ~ h}^{-\mathbf{1}}\right)$ & HRT & Unit (h) \\
\hline Influent & 2.5 & Anaerobic & 2 \\
\hline RAS & 2.5 & anoxic & 2 \\
\hline $1^{\text {st }}$ and $2^{\text {nd }}$ ICA & 7.5 and 0.75 & Aerobic & 8 \\
\hline
\end{tabular}




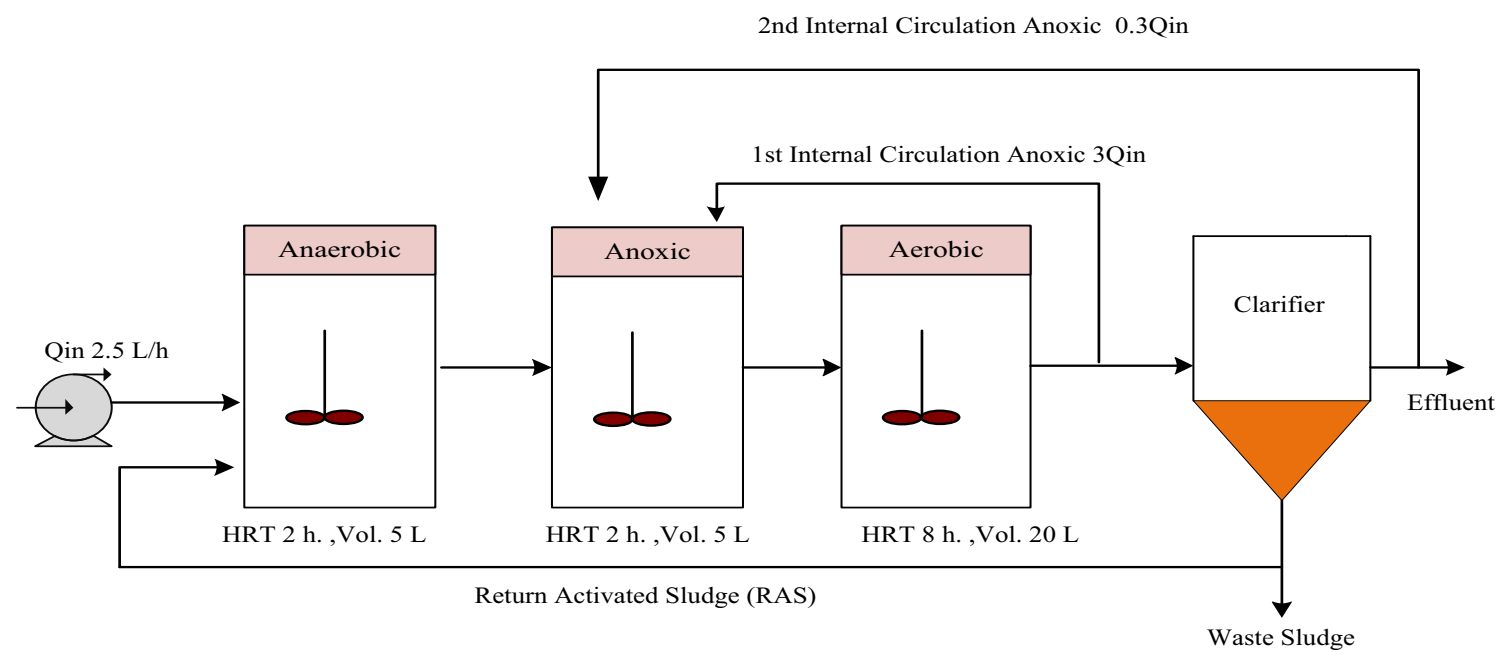

Figure 1. Schematic diagram of lab-scale BNR processes.

\subsection{Wastewater feed}

Synthetic wastewater used in this study was prepared according to Coelho et.al [1], with some modification. Wastewater contained ammonium chloride and urea as the nitrogen sources. The average concentrations of TKN and ammonia nitrogen in the fluent were $967.28 \pm 109.41$ $\mathrm{mg} \mathrm{L}^{-1}$ and $786.33 \pm 210.95 \mathrm{mg} \mathrm{L}^{-1}$. The COD in influent averaged $5,465.44 \pm 232.91 \mathrm{mg} \mathrm{L}^{-1}$. The $\mathrm{C} / \mathrm{N}$ ratio is $6.95 \pm 0.47$.

\subsection{Analytical methods}

The experiment carried on about 41 days and was considered complete when the range of changes of particular parameters in the effluent (soluble chemical oxygen demand (SCOD), total kjeldahl nitrogen (TKN), ammonia-nitrogen $\left(\mathrm{NH}_{4}^{+}-\mathrm{N}\right)$, nitrite-nitrogen $\left(\mathrm{NO}_{2}^{-}-\mathrm{N}\right)$, nitrate-nitrogen $\left(\mathrm{NO}_{3}^{-}-\mathrm{N}\right)$ within 7 days did not exceed $5 \%-10 \%$. Daily measurements of all reactors include $\left.\mathrm{SCOD}, \mathrm{TKN}, \mathrm{NH}_{4}{ }^{+}-\mathrm{N}, \mathrm{NO}_{2}^{-}-\mathrm{N}, \mathrm{NO}_{3}^{-}-\mathrm{N}\right), \mathrm{pH}$, dissolved oxygen (DO), mixed liquor suspended solids (MLSS), mixed liquor volatile suspended solids (MLVSS). The analyses were performed according to APHA [2].

\section{Results and discussion}

\subsection{Mixed liquor suspended solids (MLSS), mixed liquor volatile suspended solids (MLVSS) and SCOD}

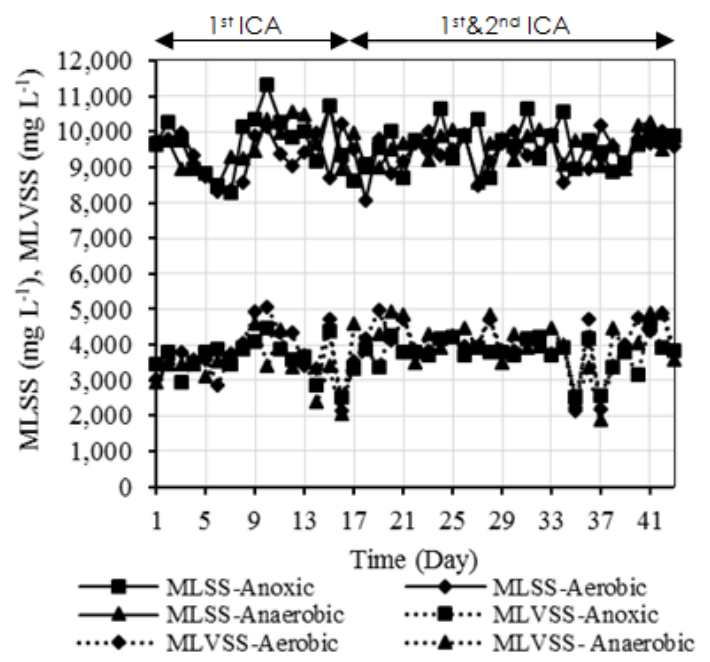

Figure 2. Performance of $\mathrm{A}^{2} / \mathrm{O}$ processes:

(A) MLSS and MLVSS in various tanks
(B) SCOD under different conditions
As shown in Fig. 2, MLSS concentration in various tanks fluctuated similarly for all conditions from day until day 41, whereas under anoxic phase MLSS was slightly higher than others. Under conditions $1^{\text {st }}$ and $2^{\text {nd }}$ ICA, from day 17 up to day 41 effluent SCOD removal was very high (Fig. 2) in comparison to under condition $1^{\text {st }}$ ICA only. Operation of $1^{\text {st }}$ ICA was between day 1 and day 16 .
The overall combined process removed $100 \%$ of SCOD. Considering that all biodegradable SCOD was then possible to calculate the biodegradable SCOD at the influent and the SCOD removal in each reactor. A quantity of SCOD removal in anaerobic, anoxic and aerobic reactors were $58.34 \%, 60.01 \%$, and 75.03 respective under $1^{\text {st }} \& 2^{\text {nd }}$ ICA. However, the MLSS trend 
is similar in both situations, $1^{\text {st }}$ ICA only and $1^{\text {st }} \& 2^{\text {nd }}$ ICA. The $2^{\text {nd }}$ ICA did not affect the MLSS. MLSS and MLVSS concentration in all the three chambers were same during the operation and remains almost constant during the whole operation period. This might be due to the equal HRTs and SRTs of all the three chambers. During 20-day SRT period the average MLSS and MLVSS concentration for all the three chamber remained constant. Within the chambers there was no noticeable effect of circulation change but on the day 35 and 37 , decrease in the average MLVSS concentration in the three chambers, where it rapidly drop to $2,345 \mathrm{mg} \mathrm{L}^{-1}$ and $2,195 \mathrm{mg} \mathrm{L}^{-1}$, respectively. After that both MLSS and MLVSS was almost stable for the three chamber at 9,620 $\mathrm{mg} \mathrm{L}^{-1}$ and 4,080 $\mathrm{mg} \mathrm{L}^{-1}$, respectively. COD removal rate for both conditions was different through the operation, affected by the changes in the circulation. Based on the average incoming SCOD concentration of 5,465.44 \pm $232.91 \mathrm{mg} \mathrm{L}^{-1}$, the removal efficiency was between $69.23 \%$ and $84.62 \%$ with the average $75.39 \%$ (Std. Dev. $=4.27$ ) for $1^{\text {st }}$ conditions, and between $99 \%$ and $100 \%$ with average $99.38 \%($ Std. Dev. $=0.61)$ for $2^{\text {nd }}$ condition, respectively.

\subsection{Dissolved Oxygen (DO) and Total Kjeldahl Nitrogen (TKN)}

Aeration to all the aerobic chamber was supplied between 2.5-5 mg- $\mathrm{O}_{2} \mathrm{~L}^{-1}$. DO concentration decreased with the increase in concentration of influent COD and ammonia. Fig. 3 , the DO concentration in the average, and increase to $0.65 \mathrm{mg}^{-} \mathrm{O}_{2} \mathrm{~L}^{-1}$ for $2^{\text {nd }}$ chamber, anoxic phase, the last chamber, aerobic first chamber, anaerobic phase, was $0.37 \mathrm{mg}^{-} \mathrm{O}_{2} \mathrm{~L}^{-1}$ on phase, and increase to $3.92 \mathrm{mg}-\mathrm{O}_{2} \mathrm{~L}^{-1}$. DO concentration influenced TKN removal efficiency, which was about $62.47 \%-73.35 \%$ and $93.06 \%-100 \%$ at conditions of only $1^{\text {st }}$ ICA and $1^{\text {st }} \& 2^{\text {nd }}$ ICA as shown in Fig. 3. Higher organic carbon concentration in the discussed accelerated the activity of heterotrophic bacteria that utilize oxygen for COD oxidation. For this reason, high initial COD concentration may result in oxygen depletion zones in activated sludge that favor nitrogen removal. Zhu et al., [3] also observed a linear relationship between SND and DO concentration, but SND was obtained even under high DO concentration (4.5 $\mathrm{mg} \mathrm{L}^{-1}$ ). The average of maintained DO concentration in $1^{\text {st }} \& 2^{\text {nd }}$ ICA is higher, $4.31 \mathrm{mg}-\mathrm{O}_{2} \mathrm{~L}^{-1}$, than in $1^{\text {st }}$ ICA only, $3.34 \mathrm{mg}-\mathrm{O}_{2} \mathrm{~L}^{-1}$, as shown in Fig. 2 . The median DO level, defined as the mid-value between the minimum and maximum DO values in given aeration period for only $1^{\text {st }} \mathrm{ICA}$ and $1^{\text {st }} \& 2^{\text {nd }} \mathrm{ICA}$, were $3.34 \mathrm{mg}$ $\mathrm{O}_{2} \mathrm{~L}^{-1}$ and $4.04 \mathrm{mg}-\mathrm{O}_{2} \mathrm{~L}^{-1}$, respectively. To obtain the true average DO concentration, integration must be performed for the DO curve during the aeration period and the division by the time; however, such integration was not performed in this experiment. Using the average DO concentration together with the minimum and maximum concentration would be the accurate way to describe the pattern of DO level.

\subsection{Removal of Ammonia by nitrification}

Nitrites was not observed at any reactor during the experiment. It was detect only in effluent. At specific circulation showed a significant impact on rate of nitrification. Working at $1^{\text {st }}$ ICA and $1^{\text {st }} \& 2^{\text {nd }}$ ICA, nitrification efficiencies were about $79.61 \%$ and $98.45 \%$, respectively. When $1^{\text {st }}$ ICA and $1^{\text {st }} \& 2^{\text {nd }}$ ICA, the residual $\mathrm{NH} 4^{+}-\mathrm{N}$ the effluent was decrease to $151.76 \mathrm{mg}-\mathrm{NH}_{4}{ }^{+}-\mathrm{N}$

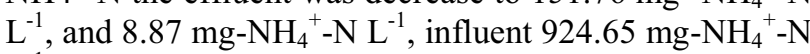
$\mathrm{L}^{-1}$.

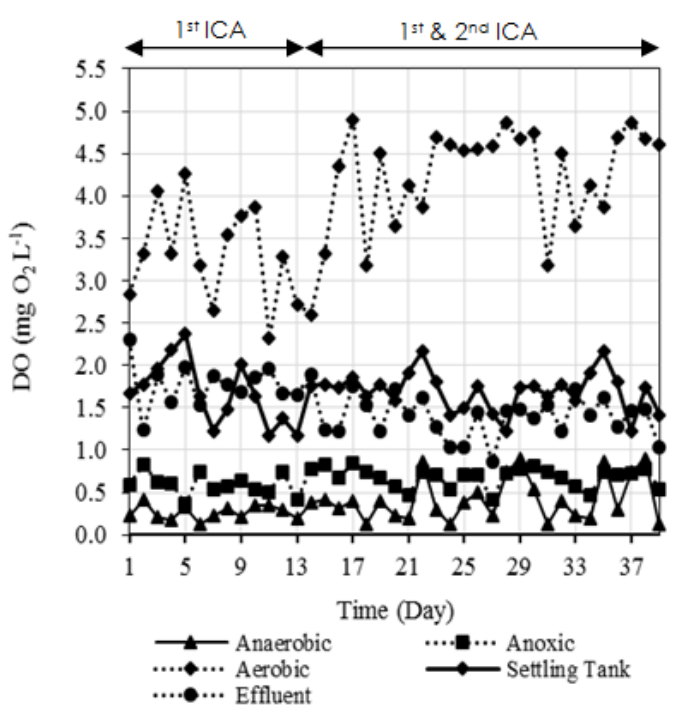

Figure 3. Performance of $\mathrm{A}^{2} / \mathrm{O}$ processes:

(A) TKN variation influent and effluent
(B) DO under different conditions
Fig. 4 (A) depicts the influent, and effluent $\mathrm{NH}_{4}^{+}-\mathrm{N}$ profiles with different conditions of operations. $\mathrm{NH}_{4}^{+}-\mathrm{N}$ was not completely converted into $\mathrm{NO}_{3}{ }^{-}$and also $\mathrm{NO}_{2}{ }^{-}$ was also detected in effluent. This is may be due to some ammonia gas losses favoured by the high $\mathrm{pH}$ in the reactor. The aerobic reactor can be operated at high $\mathrm{pH}$ value, higher than 7.5 , at this condition without affecting the nitrification process. In some of the cases the 
dissolved oxygen concentration was lower than $1 \mathrm{mg}-\mathrm{L}^{-1}$ in the aerobic chamber because of the high COD and ammonia loading rates. Under this condition, there may be the creation of some anoxic zones which resulted in the loss of $\mathrm{NO}_{3}^{-}$by simultaneous nitrification and denitrification process. Nitrogen could be removed by both assimilation into biomass and biological nitrification-denitrification process. It has been demonstrated that cell assimilation is another factor which contribute up to $15-20 \%$ of the influent TN concentration in a pre-denitrification process. The predenitrification was carried out by internal aerobic circulation nitrate rich both MLSS and liquid containing back to the anoxic reactor. The anoxic reactor was fed with the anaerobic wastewater with almost negligible $\mathrm{NO}_{3}{ }^{-}$. Average effluent $\mathrm{NO}_{3}{ }^{-}$and $\mathrm{NO}_{2}{ }^{-}$was $0.02 \mathrm{mg}-\mathrm{NO}_{3}{ }^{-}$

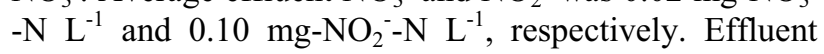
profile of $\mathrm{NO}_{3}{ }^{-}$and $\mathrm{NO}_{2}{ }^{-}$are shown in Fig. 4 (B). During aerobic mode average $\mathrm{NO}_{3}^{-}$concentrations for $1^{\text {st }}$ ICA and $1^{\text {st }} \& 2^{\text {nd }}$ ICA due to nitrification were $0.44 \mathrm{mg}^{-\mathrm{NO}_{3}}{ }^{-}$ $-\mathrm{N} \mathrm{L}^{-1}, 0.49 \mathrm{mg}^{-\mathrm{NO}_{3}-}-\mathrm{N} \mathrm{L}^{-1}$, respectively. During anoxic phase average $\mathrm{NO}_{3}^{-}$concentrations for $1^{\text {st }}$ ICA and $1^{\text {st }} \&$ $2^{\text {nd }} \mathrm{ICA}$ in the denitrifying chamber were $0.36 \mathrm{mg}^{-\mathrm{NO}_{3}}{ }^{-}-$ $\mathrm{N} \mathrm{L}^{-1}, 0.39 \mathrm{mg}-\mathrm{NO}_{3}^{-}-\mathrm{N} \mathrm{L}^{-1}$, respectively. Denitrification process requires organic carbon as electron donor. Insufficient availability of suitable organic substrate may result in poor denitrification. According to the literature, $3.3-5.0 \mathrm{~g}-\mathrm{COD} \mathrm{g}-\mathrm{NO}_{3}{ }^{-}-\mathrm{N}^{-1}$ ratio is required to achieve complete denitrification [4]. It can be noticed that in this study the supplied $\mathrm{COD} / \mathrm{NO}_{3}{ }^{-}$was more than the required, so it could not be a reason for comparatively low denitrification efficiency. The denitrification efficiency was dependent on the $\mathrm{NO}_{3}{ }^{-}$and $\mathrm{NO}_{2}{ }^{-}$recycle rate. In this experiment, $\mathrm{NO}_{3}{ }^{-}$and $\mathrm{NO}_{2}{ }^{-}$was mainly dependent on the circulation rate of both MLSS and liquid from aerobic and effluent to anoxic chamber.

\subsection{Biomass Characteristics and Variation in $\mathrm{pH}$}

Flocs with poorer settling properties are normally generated in an activated sludge treating organic matter, when the organic loading rate is high. The biomass concentration and organic loading rate (ALR) were 6.84 $\mathrm{kg}-\mathrm{NH}_{4}{ }^{+}-\mathrm{N} \mathrm{m}^{-3} \mathrm{~d}^{-1}$ and $10.97 \mathrm{~kg}-\mathrm{NH}_{4}{ }^{+}-\mathrm{N} \mathrm{m}^{-3} \mathrm{~d}^{-1}$ for ${ }_{1}{ }^{\mathrm{st}}$ ICA and $1^{\text {st }} \& 2^{\text {nd }}$ ICA, respectively. This index was between the $50-100 \mathrm{~mL} \mathrm{g-VSS}{ }^{-1}$ usually found for sludge with good settling characteristic in activated units treating organic matter [5]. A sludge with SVI of $80.79 \mathrm{~mL}$ g$\mathrm{VSS}^{-1}, 85.31 \mathrm{~mL} \mathrm{g-VSS}{ }^{-1}$ for $1^{\text {st }} \mathrm{ICA}$ and $1^{\text {st }} \& 2^{\text {nd }} \mathrm{ICA}$, respectively was obtained as shown in Fig. 5 (A). In this study, fed only with ammonia, a slightly compact sludge with high SVI was developed and, thus, it was possible to operate at slightly higher loads while maintaining higher biomass concentration in the system than those indicated for organic matter treatment. Fig. 5 (B) depicts $\mathrm{pH}$ profiles, along the length of reactor in all the three chamber (anaerobic, anoxic and aerobic), final clarifier, and effluent. The $\mathrm{pH}$ decreased in the first anaerobic chamber, and then remained almost constant from anoxic to the last aerobic chamber. Constant $\mathrm{pH}$ value from aerobic chamber suggested that the complete nitrification was achieved at this point. This was also confirmed by the $\mathrm{NH}_{4}^{+}-\mathrm{N}$ residual concentration, which was almost zero in effluent (Fig. 4 (A)). The $\mathrm{pH}$ variations along the aerobic zones are believed to be jointly caused by a number of factors. The nitrification is the most $\mathrm{pH}$ influencing process, which causes the $\mathrm{pH}$ to decrease due to alkalinity consumption. It is very important to maintain $\mathrm{pH}$ to a certain level for efficient nitrification as researchers have reported that nitrification is inhibited at a low $\mathrm{pH}$ value $(>6.5)[6]$. However, in the present system $\mathrm{pH}$ remained above 6.5 .
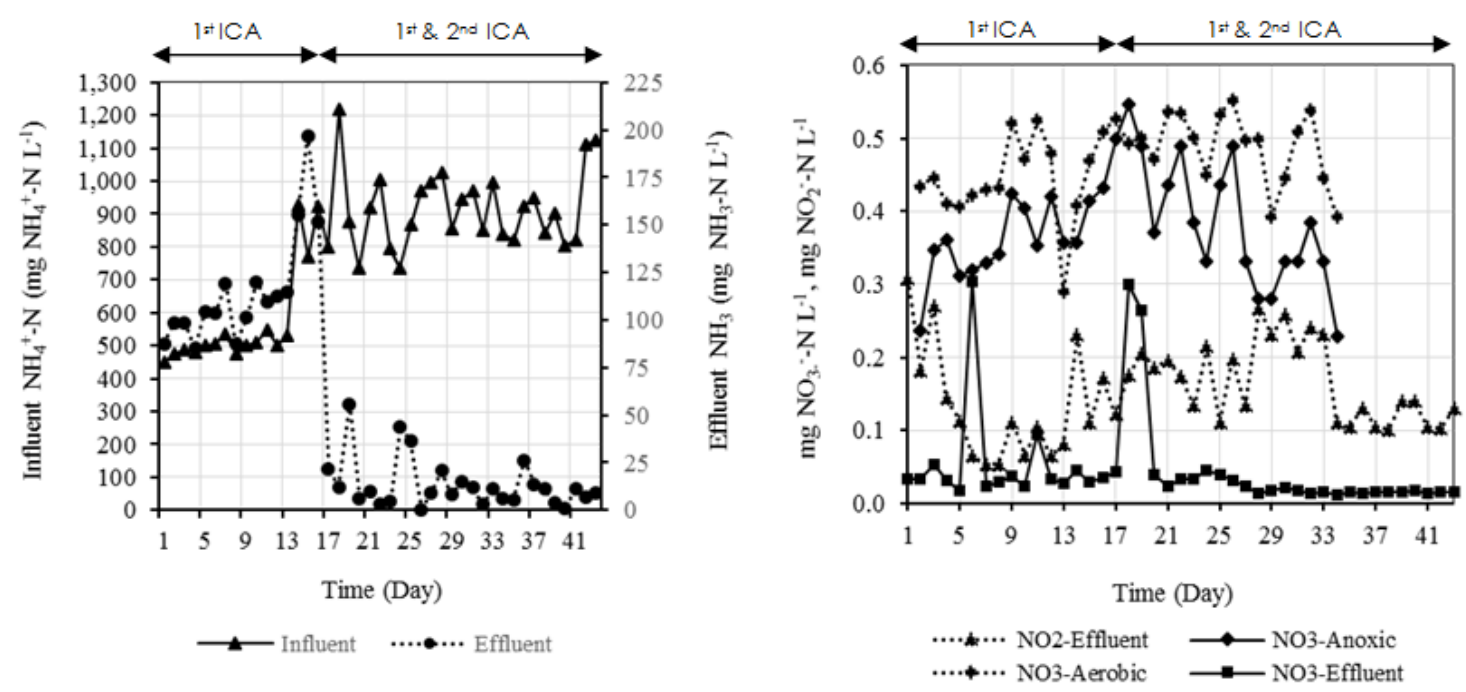

Figure 4. Performance of $\mathrm{A}^{2} / \mathrm{O}$ processes:

(A) $\mathrm{NH}_{4}{ }^{+}-\mathrm{N}$ concentration profiles

(B) $\mathrm{NO}_{3}{ }^{-}$and $\mathrm{NO}_{2}{ }^{-}$under different conditions 


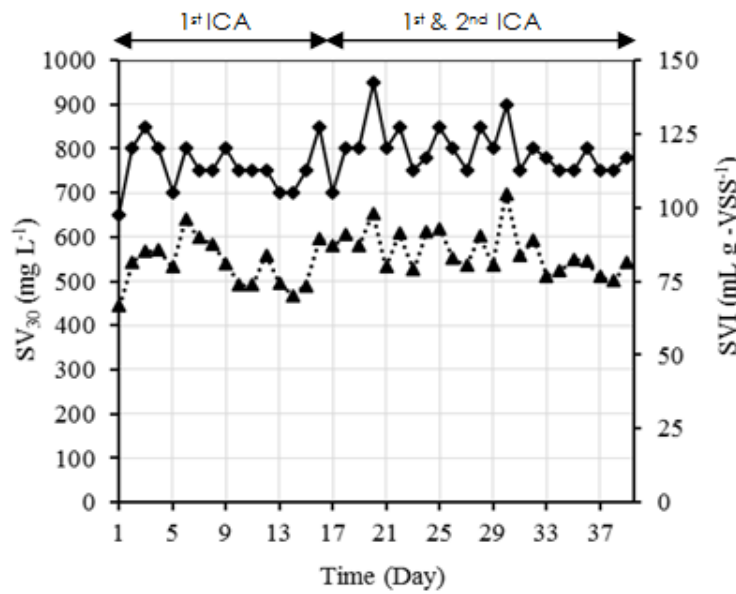

$\longrightarrow \operatorname{SV} 30(\mathrm{mg} / \mathrm{L}) \quad \cdots \cdot \cdots \mathrm{SVI}(\mathrm{mL} / \mathrm{g})$
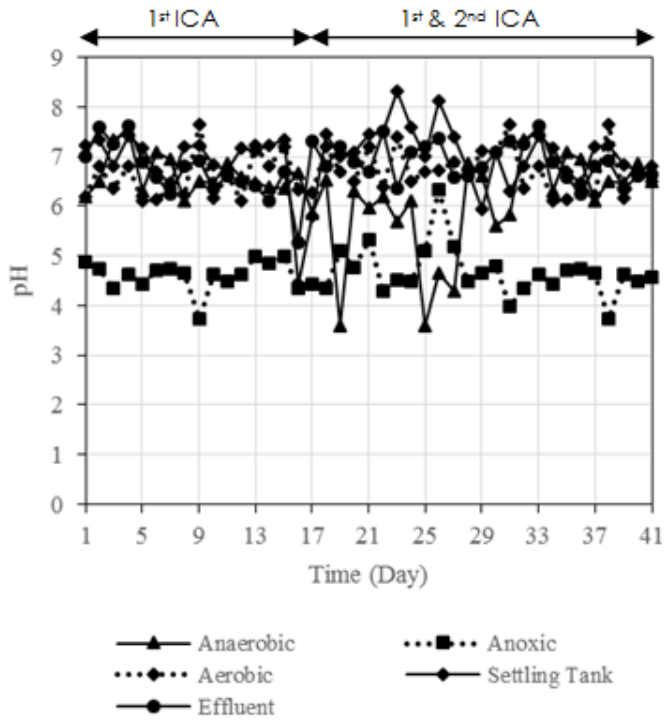

(B) Variation in $\mathrm{pH}$ change

Figure 5. Performance of $\mathrm{A}^{2} / \mathrm{O}$ processes:

(A) Variation of $\mathrm{SV}_{30}$ and $\mathrm{SVI}$

return effluent to anoxic phase can achieve discharge

\subsection{Performance of the $1^{\text {st }}$ ICA versus $1^{\text {st }} \& 2^{\text {nd }}$ ICA BNR system}

The overall performance of the $1^{\text {st }}$ ICA versus $1^{\text {st }} \& 2^{\text {nd }}$ ICA BNR system is shown in Table 2. The pollutants were efficiently in $1^{\text {st }} \& 2^{\text {nd }}$ ICA BNR system removed with SCOD 100\%, TKN removal $99.60 \%$ and $\mathrm{NH}_{4}{ }^{+}-\mathrm{N}$ removal $99.90 \%$, respectively. These parameters were better than $1^{\text {st }}$ ICA only. The removal of SCOD, TKN and $\mathrm{NH}_{4}{ }^{+} \mathrm{N}$ are $84.62 \%, \quad 73.35 \%$ and $97.27 \%$, respectively. The $1^{\text {st }} \& 2^{\text {nd }}$ ICA BNR system is superior to the $1^{\text {st }}$ ICA BNR system only using in coupling $2^{\text {nd }}$ ICA. Because under anoxic conditions heterotrophs utilize organic matter as electron donor and $\mathrm{NO}_{3}-\mathrm{N}$ act as electron donor. As a result, under conditions high carbon and $\mathrm{NO}_{3}-\mathrm{N}, \mathrm{N}_{2}$ production can generate higher than with $1^{\text {st }}$ ICA BNR system only.

Table 2. Overall effluent by $1^{\text {st }}$ and $1^{\text {st }} \& 2^{\text {nd }}$ ICA BNR system

\begin{tabular}{|c|c|c|c|c|}
\hline Sys. & $\begin{array}{c}\mathrm{SCOD} \\
\mathrm{mg} \mathrm{L}^{-1}\end{array}$ & $\begin{array}{c}\mathrm{TKN} \\
\mathrm{mg}-\mathrm{NH}_{4}{ }^{+}-\mathrm{N} \mathrm{L}^{-1}\end{array}$ & $\begin{array}{c}\mathrm{NH}_{4}{ }^{+}-\mathrm{N} \\
\mathrm{mg}-\mathrm{NH}_{4}{ }^{+}-\mathrm{N} \mathrm{L}^{-1}\end{array}$ & $\begin{array}{c}\mathrm{NO}_{3}{ }^{-}-\mathrm{N} \\
\mathrm{mg}^{-}-\mathrm{NO}_{3}{ }^{-}-\mathrm{N} \mathrm{L}^{-1}\end{array}$ \\
\hline $1^{\text {st }} \mathrm{ICA}$ & 1,328 & 60.48 & 21.75 & 0.04 \\
\hline $\begin{array}{c}1^{\text {st }} \& 2^{\text {nd }} \\
\text { ICA }\end{array}$ & 0 & 0 & 1.12 & 0.01 \\
\hline
\end{tabular}

\section{Conclusion}

Internal circulation (IC) of activated sludge anaerobic and anoxic/oxic processes was used to treat high carbon and nitrogen synthetic wastewater. The research proved that standard. Treatment only with $1^{\text {st }}$ ICA BNR system, the discharge cannot meet the standard. The $2^{\text {nd }}$ ICA with 0.3 in has shown a great advantage. The $1^{\text {st }} \& 2^{\text {nd }}$ ICA BNR system could remove $100 \%$ of SCOD, $99.60 \%$ of TKN, and $99.90 \%$ of $\mathrm{NH}_{4}^{+}-\mathrm{N}$. The organic loading rate and $\mathrm{NH}_{4}{ }^{+}-\mathrm{N}$ loading rate are $68.38 \mathrm{~kg}-\mathrm{COD} \mathrm{m}{ }^{-3} \mathrm{~d}^{-1}$ and $9.86 \mathrm{~kg} \mathrm{NH}_{4}{ }^{+}-\mathrm{N} \mathrm{m}^{-3} \mathrm{~d}^{-1}$, respectively.

\section{References}

1. Coelho M. A. Z., Russo C., Araújo O. Q. F. Optimization of a sequencing batch reactor for biological nitrogen removal. Water Res. 34, 10 (2000)

2. APHA, AWWA, WEF, Standard methods for the examination of water and wastewater $\left(18^{\text {th }}\right.$ ed.). APHA, AWWA. WEF, Washington DC. (1992)

3. Zhu G. B., Peng Y. Z., Wu S. Y., Wang S. Y., Xu S. $X$. , Simultaneous nitrification and denitrication in step feeding biological nitrogen removal process, J Environ Sci , 19, 9 (2007)

4. K. Karim, S. K. Gupta. Continuous biotransformation and removal of nitrophenols under denitrifying conditions. Water Res. 37, 12 (2003)

5. D. H. Eikelboom and H. J. J, van Buijsen, TNO Report A94A, Microscopic sludge investigation manual TNO Research Institute for Environmental Hygiene. Water and Soil Division, Delft, The Netherlands, (1981)

6. Bae W, Baek S., Chung J., Lee Y. Optimal operational factors for nitrite accumulation in batch reactors. Biodegradation 12, 5 (2002) 